\title{
Contextual Factors in Higher Education: Impact on My Teaching and Learning @ University of Venda
}

\author{
Gumbo JR
}

\begin{abstract}
The number of Higher Education Institutions (HEIs) throughout the world have increased tremendously in line with population increases and the economic and often government-driven social changes. This increased enrolment has resulted in a growth in the number of university students who do not complete their academic studies in the prescribe times and others who drop out of the university systems without any form of qualification. The reasons for the increased drop-out rates, though not limited to these, include: lack of financial resources to continue with the studies and/or to complete the studies; poor transition from secondary schooling to university; lack of resources, such as laboratories, at HEIs; and lack of academic preparedness as well as poor educational background. The South African HE landscape has not been spared from the various global experiences as we now live in this digital global village. Nevertheless, the country has its unique circumstances in that it multi-racial attained democracy in 1994 and the political order that was ushered in introduced a program seeking to transform all higher education institutions (HEIs). This transformation exercise has over the years involved the merging of non- HEI such polytechnics, technikons and colleges and de-establishment of others HEIs and the creation of comprehensive universities and universities of technology in the country's HEI landscape. The then University of Venda for Science and Technology was transformed into a comprehensive university embodying all of the above attributes which also now form part of the University of Venda's vision, mission and institutional values. The University of Venda is located in the Vhembe District of the Limpopo Province and the majority of its student enrolment is from this district and province as well as a minority from other provinces of South Africa and a much smaller number from the South African Development Community (SADC), West and East Africa and other regions of the world. The School of Environmental Sciences was established in 1995 to usher in new programs that offered four year professional degrees and two year diplomas as part of the transformation into a comprehensive university. The Department of Hydrology and Water Resources offers a four year professional the degree of Bachelor of Earth Sciences in Hydrology and Water Resources (BES HWR).
\end{abstract}

Index Terms - transformation in South Africa, underprepared students, walk in students, student drop out

J.R.G is with Department of Hydrology \& Water Resources, University of Venda..

\section{INTRODUCTION}

This paper discusses the way in which contextual factors impact on my teaching and learning. The number of Higher Education Institutions (HEIs) throughout the world have increased tremendously in line with population increases and the economic and often government-driven social changes [1]. The HEI landscape has also witnessed a plethora of diversity that includes the establishment of traditional universities, comprehensive universities and universities of technology. This increase has also gone hand in hand with the massification of student's intakes from various backgrounds, nationalities, cultures and socio-economic status.

\section{INTERNATIONAL CONTEXT}

This increased enrolment has resulted in a growth in the number of university students who do not complete their academic studies in the prescribe times and others who drop out of the university systems without any form of qualification. The reasons for the increased drop-out rates, though not limited to these, include: lack of financial resources to continue with the studies and/or to complete the studies; poor transition from secondary schooling to university; lack of resources, such as laboratories, at HEIs; and lack of academic preparedness as well as poor educational background [2]. Pathirana et al.[3] state that even UNESCO-IHE was offering a didactic certification program to empower the lecturers to become part of facilitative active learning in order for students to become constructivist, a process based on the theory of constructive alignment. Thus, I concur with an international perspective that states that a lecturer must be able to acquire socio-constructivism theories of teaching and learning, hence my enrolment in this post graduate diploma in higher education study programme.

The higher education (HE) sector, national and international, is changing in response to government interventions seeking to increase the student numbers and to make the academy responsive to society and the economy [4,5]. The study of Barnett [6] shows that internationally, the monopoly HE of knowledge and knowledge generation belonged to history with the entry of private enterprises. This was in response to rapid changes in information and communication technologies (ICTs); and a new global economy based on information and knowledge and the needs of the workplace.

The increase of institutions of higher learning in response to the demand of knowledgeable workplaces means that the academy and workplace must co-exist [7]. This peaceful 
co-existence demands that there be changes to the HE curriculum, especially in the field of teaching and learning, to equip the students with 'general transferable skills' and facilitate their lifelong learning [7] and critical cross field outcomes (CCFOs) [8]. The issue of 'general transferable skills' has been taken up by the South African Qualification Authority (SAQA) through its review of all qualifications in South Africa, incorporation of 'critical outcomes' and outlining of a list of general transferable skills [7].

Luckett [7] indicates that the undergraduate curriculum review in Australia had a compulsory core of generic skills and electives. In addition, a study was carried out in South Africa re-visit the curriculum and increase the undergraduate completion times through programs such as the Extended Degree Programs [8] and use of the Foundation Programs in order to assist the underprepared students to make a successful transition to university life and completion of their degrees [8].

\section{NATIONAL CONTEXT}

The South African HE landscape has not been spared from the various global experiences as we now live in this digital global village. Nevertheless, the country has its unique circumstances in that it multi-racial attained democracy in 1994 and the political order that was ushered in introduced a program seeking to transform all higher education institutions (HEIs). This transformation exercise has over the years involved the merging of non- HEI such polytechnics, technikons and colleges and de-establishment of others HEIs and the creation of comprehensive universities and universities of technology in the country's HEI landscape [1]. This was indeed a significant project, which, according Ogude et al. [5], meant that HEIs were 'expected to be vehicles of social redress by broadening access, improving success rates, and setting targets for improved racial and gender balances' and to respond to societal and economic needs of South Africa.

A majority of the HEIs are funded by national governments and the students receive state subsidies to continue with their studies as in the case of South Africa [9]. However, the educational authorities and government officials dealing with HEIs are alarmed at the high rate of drop outs and have formulated different strategies to manage these challenges and opportunities in the South African context. Some of the strategies involve re-visiting the curriculum and increasing the completion times through the introduction of the Extended Degree Programs [2] and use of the Foundation Programs to assist the underprepared students and ensure that make it in the university system [2]; and the establishment of centres of higher education teaching \& learning such as the University of Venda, Centre for Higher Education Training and Learning (CHETL) at every HEI to empower the educators (lecturers) with new teaching and learning approaches [1].

The post-1994 transformation of the HEI landscape in South Africa, as already noted the merging of a number of the country's tertiary institutions into comprehensive universities and universities of technology. My experiences with issues of transformation, however, are linked to the way our University of Venda was transformed into a comprehensive university. Thus, in addition to offering the 'traditional degrees', we are expected to develop diploma and certificate programs for some students who cannot enroll for degree programs. I have been involved in the development of Certificate qualification in Water and Wastewater Services, a process that has however been put on hold. Instead we have been instructed to develop a new curriculum in Water Engineering degree program.

The students have also been affected by the post-1994 transformation project. There has been a massification of student intakes over the years, as evidenced by these increases: in 1985 the student population at HEIs was 270,874 and by 2007 the student population had risen to 759,093 , which is a massive increase of $180.2 \%$ [10]. The University of Venda, here, also had its fair share of increased student population, from a mere 3,202 in 1982 to a whopping 11,000 student population in 2012 [11].Though there has been an impressive increase in student enrolments over the years, the drop outs have been high, as noted in the statistics in which the 2002 first year student enrolment stood at 138,000 and yet five years later, in 2007 , only 46,200 students graduated (33.38\% of the enrolled students and with a staggering 71,200 having students dropped out (51.80\%) and 20,600 students still studying (14.93\%) [10]. The reasons for the huge student dropouts are similar to global trends but, local factors, such as poor educational background and extreme poverty, could account for such large numbers of drop outs [2].

\section{INSTITUTIONAL CONTEXT}

The University of Venda's experiences of this transformation involved the dropping its science and technology signature to adopting a plain 'University of' and a march towards the paradigm of a comprehensive university. The then Department of Education [12] stated that some of the attributes for a comprehensive university were:

- Diversity - through the offering of a diverse range of academic programmes (vocational, career-focused, professional and general formative) of both university and technikon type.

- Accessibility - through the opportunities created by a variety of entry and exit points.

- Student mobility - through developing strong vertical and horizontal articulation pathways.

- Responsiveness - through the development of a suite of educational programmes and research foci appropriate to local, regional and national needs.

- Flexibility - through the strengthening of relationships with community, civic, government, business, and industry partners for local and regional development.

- Flexibility should characterise the institutions' ability to meet the human resource needs of the local (and wider) context through its training programmes, and to

- Contribute to the development of the communities it serves through the application and extension of its knowledge and expertise'.

The then University of Venda for Science and Technology was transformed into a comprehensive university embodying all of the above attributes which also now form part of the University of Venda's vision, mission and institutional values 
[13]. The University of Venda is located in the Vhembe District of the Limpopo Province and the majority of its student enrolment is from this district and province as well as a minority from other provinces of South Africa and a much smaller number from the South African Development Community (SADC), West and East Africa and other regions of the world [11,14-16]. However the Limpopo Province, one of the nine provinces of South Africa, is rural in outlook and its main economic activity is agriculture with rural farmers practising subsistence farming $[17,18]$. The situation in 2006 was such that a majority of the province's rural public schools had water and sanitation challenges with pit latrines as the sanitary system of choice [19]. Hence, the University's transformed position has met with a number of challenges, especially in the areas of resource and service facilitation from its major enrolment feeder communities, a condition that nevertheless makes my areas of teaching in water, sanitation and waste management significant to the community.

However, some of the challenges faced by learners result from the articulation gap between the school and the university. These challenges include lack of preparedness; poor English language proficiency; and lack of mathematical and physical sciences and numeracy skills [20], all of which are prerequisites for a learner intending to study a program in Bachelor of Earth Sciences in Hydrology and Water Resources. According to the matric results of 2013, Limpopo province performed badly coming second from last [21].Thus, secondary students who intend to enroll at the University of Venda are affected by multiple challenges such as lack of resources, books, and infrastructure, poor roads network which is made worse during the rainy season or extreme weather events, and lack of finance from their parents to enable them to continue with primary or secondary schooling [22-24].

Therefore, the students who enroll at the University of Venda come from diverse educational backgrounds associated with Limpopo Province's social and economic status. Some of the students are under prepared and some are walk in students. This means that from my part I must go the extra mile to motivate the students and make the learning environment more interesting for the new students. As a result, I have frequently used educational movies from www.youtube.com as part of my teaching and learning strategy with my students at the University of Venda.

\section{DEPARTMENTAL CONTEXT}

The School of Environmental Sciences was established in 1995 to usher in new programs that offered four year professional degrees and two year diplomas [11] as part of the transformation into a comprehensive university. The Department of Hydrology and Water Resources offers a four year professional the degree of Bachelor of Earth Sciences in Hydrology and Water Resources (BES HWR); a one year Bachelor of Earth Sciences Hons in Hydrology and Water Resources (BES Hons HWR); a two year Masters by research (Masters in Hydrology and Water Resources) and three year $\mathrm{PhD}$ by research (PhD in Hydrology \& Water Resources).

Being a senior lecturer in the Department of Hydrology and Water Resources, I train students as part of improving the scarcity of skills and knowledge of professionals in the water sector of South Africa (local and national mandate), SADC (regional mandate) and Africa and world in general [11]. I am also registered as a water care expert with South African Council for Natural Scientific Professions (SACNASP).

The curriculum of the undergraduate modular program, Bachelor of Earth Sciences in Hydrology and Water Resources and post-graduate degree, and the Bachelor of Earth Sciences in Honours in Hydrology and Water Resources, should be registered with the South African Qualifications Authority (SAQA) ${ }^{1}$. SAQA is a legislative body tasked with the administration of the National Qualifications Framework $(\mathrm{NQF})^{2}$. The curriculum should be accredited with the Council for Higher Education and registered with the Department of Higher Education and Training. The objectives of NQF [25] are:

- Create a single, integrated national framework for learning achievements

- Facilitate access to, and mobility and progression within, education, training and career paths

- Enhance the quality of education and training

- Accelerate the redress of past unfair discrimination in education, training and employment opportunities

- Contribute to the full personal development of each learner and the social and economic development of the nation at large.

In South Africa, the majority of service delivery protests are based on lack of access to basic water services, either for human consumption and or to meet sanitation systems [26]. Even the United Nations, declared in 2005 that, the following 10 years, from 2005 to 2015 was the 'Water decade', thus indicating its seriousness with regards to access to basic water services, a goal that also means that professional water experts are required to facilitate the realization of these noble goals [27-28]. Thus, my training of water professionals is an attempts at meeting the gap and challenges faced by South Africa in the water service delivery services.

\section{CONCLUSION}

The number of Higher Education Institutions (HEIs) throughout the world have increased tremendously due to population increases and the economic development. In response to societal concerns governments have been forced to increase the number of HEIs and also manage the high number of university drop out. In South Africa, this issue of transformation exercise has involved the merging of non- HEI such polytechnics, technikons and colleges and de-establishment of others HEIs and the creation of comprehensive universities and universities of technology in the country. The former University of Venda for Science and Technology was transformed into a comprehensive university and repositioning itself as regional university serving the Southern Africa region. At departmental level there is a need to review the curriculum in line with new University vision and the

\footnotetext{
${ }^{1}$ The NQF was established under the SAQA Act (Act 58 of 1995) and continues under the NQF Act (Act 67 of 2008) which came into effect on 1 June 2009.

${ }^{2}$ National Qualifications Framework (NQF) Act, no. 67 of 2008
} 
interests of the stakeholders such as the professional bodies, employers, former students, the provincial government, the industry and the local community.

\section{ACKNOWLEDGMENT}

The author was provided with a scholarship to undertake post graduate diploma in Higher Education at Rhodes University by the University of Venda, Teaching and Development Grant 0791.

\section{REFERENCES}

[1] Scott, I, (2009). First-year Experience as Terrain of failure of Platform for Development? Critical Choices for Higher Education. In B. Leibowitz A Van der Merwe and S Van Schalkwyk (Eds). Focus on First Year Success: perspectives Emerging from South Africa and Beyond. Stellenbosch: SUN PReSS.

[2] Council on Higher Education (CHE), (2013a). A proposal for undergraduate curriculum reform in South Africa: The case for a flexible curriculum structure.

http://www.che.ac.za/sites/default/files/publications/Full_Report.pdf (date accessed 25/03/2014)

[3] Pathirana, A., Koster, J.H., de Jong, S., Uhlenbrook, S. (2012). On teaching styles of water educators and the impact of didactic training. Hydrol. Earth Syst. Sci. 16: 3677-3688.

https://doi.org/10.5194/hess-16-3677-2012

[4] Johnston, R. (1998). The University of the Future: Boyer revisited. Higher Education, 36(3), 253-272. https://doi.org/10.1023/A:1003264528930

[5] Ogude, N., Nel, H., \& Oosthuizen, M. (2005). The challenge of curriculum responsiveness in South African higher education.

[6] Barnett, R. (1994). The limits of competence: knowledge, higher education and society. Open University Press, 1900 Frost Rd., Suite 101, Bristol, PA 19007.

[7] Luckett, K. (2001). A proposal for an epistemically diverse curriculum for South African higher education in the 21st century. South African Journal of Higher Education, 15(2), p-49. https://doi.org/10.4314/sajhe.v15i2.25354

[8] Nkomo, M. (2000). The National Qualifications Framework and Curriculum Development. Pretoria: South African Qualification Authorities.

[9] Le Roux P, Breier M (2007). Steering from a distance. Improving aces to higher education in South Africa via the funding formula. http://www.fes-outhafrica.org/media/Le\%20Roux\%20and\%20Breier\%2 0FES\%20style\%2030\%20Oct\%20\%283\%29\%20-\%202012-11-12.pdf( date accessed 26/03/2014)

[10] South African Transformation Monitor (SAT Monitor) n.d http://www.navorsing.co.za/wp-content/uploads/2010/07/SAT\%20MO NITOR_Education.pdf (Date accessed 26/03/2014)

[11] University of Venda (Univen) (2012a). Univen History book http://www.univen.ac.za/docs/Univen\%20History\%20Book.pdf(date accessed 26/03/2014)

[12] Department of Education (DoE), (2004). Creating Comprehensive Universities in South Africa: A Concept Document. January 2004 www.gov.za/documents/download.php? $f=70361$ (date accessed 26/03/2014)

[13] University of Venda (Univen) (2014a). Vision and Mission of the University of Venda http://www.univen.ac.za/index.php(date accessed 26/03/2014)

[14] University of Venda (Univen) (2012b). Nendila (date accessed 25/07/2014) http://www.univen.ac.za/docs/nendila/NendilaAprilMay2012low.pdf (date accessed 25/07/2014)

[15] University of Venda (Univen) (2012c). Univen strategic plan 2012-2016 http://www.univen.ac.za/docs/UnivenStratDoc2012New_Lowres.pdf(da te accessed 25/07/2014)

[16] University of Venda (Univen) (2012d). Univen Annual Report http://www.univen.ac.za/docs/UnivenAnnualReport2012_Low.pdf(date accessed 25/07/2014)
[17] Bradshaw, D., Nannan, N., Laubscher, R., Groenewald, P., Joubert, J., Nojilana, B., Norman, R., Pieterse, D., Schneider, M. (2000). Mortality estimates for Limpopo Province, 2000. South African national Burden of Disease Study. http://www.mrc.ac.za/bod/limpopo.pdf (date accessed 26/03/2014)

[18] Department of Education (DoE) (2011). A provincial level picture of health, education and poverty in South Africa, 2011 http://www.education.gov.za/LinkClick.aspx?fileticket=mgLSdNZZTB A\%3D\&tabid=93\&mid=1952 (date accessed 26/03/2014)

[19] Sibiya, J.E., Gumbo, J.R. (2013). Knowledge, Attitude and Practices (KAP) Survey on Water, Sanitation and Hygiene in Selected Schools in Vhembe District, Limpopo, South Africa. Int. J. Environ. Res. Public Health. 10, 2282-2295 https://doi.org/10.3390/ijerph10062282

[20] Department of Basic Education (DoE), (2009). National Examinations and Assessment. Report on the national Senior Certificate Examination Results, 2009.

http://www.education.gov.za/LinkClick.aspx?fileticket=13hlVk9sypk\%3 D\&.(date accessed 26/03/2014)

[21] Times Live report of 10 January (2014). MEC unaware of Limpopo school failures: report

http://www.timeslive.co.za/local/2014/01/10/mec-unaware-of-limpopo-s chool-failures-report(date accessed 26/03/2014)

[22] McKenna S, (2004). The interaction between academic literacies and student identities. SAJHE. 18:269-280.

[23] UNICEF (2008). Unicef UK Climate Change Report 2008. Our climate, our children, our responsibility. The implications of climate change for the world's children

http://www.childreninachangingclimate.org/database/unicef/Publication s/Our\%20climate\%20our\%20children\%20our\%20responsibility.pdf(dat e accessed 26/03/2014)

[24] Department of Education (DoE) (2012). Report: Verification of text books deliveries in Limpopo. http://www.education.gov.za/LinkClick.aspx?fileticket=4V3T5651NZU $\% 3$ D\&tabid $=347$ (date accessed 26/03/2014)

[25] National Qualifications Framework (NQF) Act, no. 67 of 2008

[26] Tapela, B. (2013).Social Protests and Water Service Delivery in South Africa: Characterisation of Selected Local Contexts.

http://www.plaas.org.za/sites/default/files/publications-landpdf/Media\% 20Briefing $\% 20$ Summary $\% 20-\% 20$ Social $\% 20$ Protests $\% 20$ and $\% 20$ Wate r\%20Service\%20Delivery\%20in\%20South\%20Africa\%20-\%20Barbara \%20Tapela.pdf (date accessed 26/03/2014)

[27] Thompson, S.E., Ngambeki, I., Troch, P.A., Sivapalan, M., Evangelou, D. (2012). Incorporating student-centred approaches into catchment hydrology teaching: a review and synthesis. Hydrol. Earth Syst. Sci. 16: 3263-3278.

https://doi.org/10.5194/hess-16-3263-2012

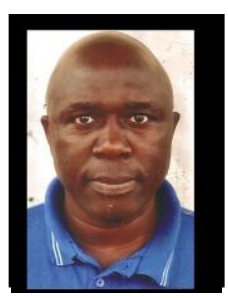

Jabulani Ray Gumbo obtained a $\mathrm{PhD}$ in Water Resources Management from University of Pretoria in 2007. He was awarded the second best student poster price at the $12^{\text {th }}$ International Conference on Harmful Algae in 2006 and the study was then published in the prestigious conference proceedings after a rigorous peer review process. This author became a Member (M) of International Society for the Study of Harmful Algae; International Mine Water Association; Water Institute of Southern Africa; Microscopy Society of Southern Africa and South African Council for Natural Scientific Professions. In 2008, he was appointed as a senior lecturer at University of Venda and in 2016 he was appointed as Associate Professor. He is the first or second author of more than 60 peer reviewed papers, conference proceedings and co-authored 5 book chapters. He acts as a reviewer for NRF in the fields of cyanobacteria and has been invited to be a reviewer for Ohio Sea Grant Proposal (USA); Journal of Applied Phycology (Australia); Bioresource Technology Journal (BITE) (USA); Journal of Freshwater Ecology (Britain); South African Journal of Science (SAJS) (South Africa) and African Journal of Biotechnology (AJB) (Nigeria). He lectures students at undergraduate and postgraduate levels in the fields of water treatment; water quality management; water law and institutions; rural water supply and sanitation; data information systems and water quality principles and he supervises 
10th Int'I Conference on Advances in Science, Engineering, Technology \& Healthcare (ASETH-18) Nov. 19-20, 2018 Cape Town (South Africa)

several Honours, Masters and $\mathrm{PhD}$ students in the fields of water quality management; aquatic ecotoxicology and limnology and water treatment. He is the holder of three patents. 